\title{
Peningkatan Keterampilan Menulis Teks Anekdot Menggunakan Strategi Pembelajaran Think Pair Share pada Siswa Kelas X
}

\author{
Iqlima \\ IKIP PGRI Pontianak \\ Program Studi Pendidikan Bahasa dan Sastra Indonesia \\ brentex32@yahoo.co.id
}

\begin{abstract}
Abstrak
Penelitian ini bertujuan untuk mengetahui penerapan metode Think Pair Share (TPS) dalam meningkatkan keterampilan menulis teks anekdot. Penelitan tindakan kelas ini terdiri dari 2 siklus setiap siklusnya terdiri dari empat tahapan yaitu perencanaan, pelaksanaan, observasi, dan refleksi. Subjek penelitin ini adalah siswa kelas X SMA N 1 Tebas. Data diperoleh melalui pengamatan, wawancara, tes, dan dokumentasi. Teknik analisis data dalam penelitian ini menggunakan Teknik analisis statistik deskriptif komparatif dan analisis kritis. Hasil penelitian menunjukkan bahwa penerapan metode TPS dapat meningkatkan keterampilan menulis teks anekdot, yaitu siklus 1 diperoleh nilai rata-rata 74,55 dan siklus 2 diperoleh nilai rata-rata sebesar 78 .
\end{abstract}

Kata Kunci: menulis, teks anekdot, TPS

\section{PENDAHULUAN}

Pembelajaran bahasa Indonesia memiliki empat keterampilan, yaitu keterampilan menyimak, keterampilan berbicara, keterampilan membaca, dan keterampilan menulis. Kemampuan menulis merupakan suatu kegiatan menuangkan gagasan ide, inspirasi, atau buah pikiran manusia ke dalam bentuk lambang-lambang grafis yang menggambarkan suatu bahasa agar orang lain dapat memahaminya. Tinjauan dari segi pemerolehan, menulis adalah aspek berbahasa keempat yang diperoleh melalui proses pembelajaran di sekolah. Seorang pelajar dituntut terampil dalam menulis, serta menuangkan ide dan gagasan pada sebuah tulisan, maka pengembangan keterampilan menulis dapat menentukan keberhasilan siswa dalam mengikuti proses belajar mengajar. Dengan menulis, seseorang dapat menggambarkan pola pikirannya terhadap ide dan gagasan yang dihasilkannya. Seperti yang disampaikan oleh Tarigan (2008:22) menulis ialah menurunkan atau melukiskan lambanglambang grafik yang menggambarkan suatu bahasa yang dipahami oleh 
seseorang, sehingga orang lain dapat membaca lambang-lambang grafik tersebut kalau mereka memahami bahasa dan gambaran grafik itu. Semi (2007:14) mengatakan menulis merupakan suatu proses kreatif memindahkan gagasan ke dalam lambang-lambang tulisan. Dalam pengertian ini, menulis itu memiliki tiga aspek utama. Pertama, adanya tujuan dan maksud tertentu hendak dicapai. Kedua, adanya gagasan atau sesuatu yang hendak dikomunikasikan. Ketiga, adanya sistem pemindahan gagasan itu, yaitu berupa sistem bahasa. Sehubungan dengan pendapat tersebut, Nurgiyantoro (2010:425) mendefinisikan menulis adalah aktivitas mengemukakan gagasan melalui media bahasa. Terkait dengan pendapat tersebut, Kusumangingsih, dkk.(2013:65) mendefinisikan menulis adalah kegiatan menyampaikan sesuatu menggunakan bahasa melalui tulisan, dengan maksud dan pertimbangan tertentu untuk mencapai sesuatu yang dikehendaki. Hal ini menunjukan bahwa, menulis merupakan suatu keterampilan berbahasa yang dipergunkan untuk berkomunikasi secara tidak langsung, tidak secara tatap muka dengan orang lain.

Berbicara mengenai menulis ada banyak sekali satu diantaranya adalah menulis teks anekdot. Teks Anekdot adalah cerita singkat, lucu, konyol, dan mengesankan dari tokoh ataupun peristiwa tertentu. Menurut (Keraf, 1981:142) anekdot adalah semacam cerita pendek yang bertujuan menyampaikan karakteristik yang menarik atau aneh mengenai seseorang atau suatu hal lain. Sehubungan dengan pendapat di atas, Danandjaja (Rohmadi, 2011:133-134) mendefinisikan anekdot sebagai dongengdongeng yang dapat menimbulkan rasa menggelikan hati sehingga menimbulkan ketawa bagi yang mendengarnya maupun yang menceritaknnya.

Selaras dengan pengertian Teks anekdot menurut para ahli di atas, Priyatni (2014:93) mengatakan teks anekdot adalah teks yang memaparkan cerita singkat yang menarik karena lucu dan mengesankan yang isinya berupa kritik atau sindiran terhadap kebijakan, layanan publik, perilaku penguasa, atau suatu fenomena/kejadian. Berdasarkan pendapat para ahli di atas dapat disimpulkan bahwa anekdot adalah sebuah cerita singkat yang lucu dan menarik, yang mungkin menggambrakan tentang kejadian tertentu atau orang sebenarnya.

Berdasarkan hasil wawancara dan hasil observasi peneliti kepada guru mata pelajaran bahasa Indonesia, Ibu Rusdiana, S.Pd peneliti mendapat informasi bahwa kemampuan siswa menulis teks anekdot di $\begin{array}{lllll}\text { kelas } & \mathrm{X} & \text { SMA Negeri } 1 & \text { Tebas }\end{array}$ dikategorikan masih relatif rendah. Hal ini dilihat dari kesulitan siswa pada saat 
menulis teks anekdot dengan bahasa yang lucu, penuh humor, dan kata sindiran. Hal tersebut terjadi dikarenakan dari dua faktor yaitu dari siswa itu maupun faktor guru, dilihat faktor guru berdasarkan observasi, gurunya masih menggunakan metode ceramah, sehingga waktu yang diselenggarakan pada pembelajaran habis untuk guru itu sendiri dalam menjelaskan, dan siswa di sini tidak diberikan ruang gerak atau kesempatan untuk menemukan hal-hal penting pada saat proses pembelajaran berlangsung. Guru hanya mengajarkan sampai teori, tidak disertai dengan memberikan kesempatan kepada siswa untuk mengetahui langkah-langkah dalam menulis teks anekdot. Sedangkan dari faktor siswanya, siswa kurang antusias saat mengikuti pembelajaran.

Berdasarkan dari uraian permasalahan yang ada maka diperlukan suatu strategi pembelajaran yang dapat membantu siswa untuk berpikir dan berbagi dalam meningkatkan keterampilan menulis. Satu diantara usaha yang dilakukan adalah dengan menerapkan strategi pembelajaran yang sesuai dengan materi serta menarik perhatian siswa dan juga mempermudah pemahaman yang pada akhirnya bermuara pada peningkatan kuaitas pembelajaran menggunakan strategi pembelajaran Think-Pair Share.

\section{KAJIAN TEORI}

Strategi pembelajaran think-pair share adalah strategi pembelajaran yang mempunyai konsep dalam pelaksanaannya yang terdiri "thinking", pembelajaran ini diawali dengan mengajukan suatu pertanyaan atau isu yang terkait dengan pembelajaran yang dipikirkan. Selanjutnya “pairing”, membentuk berpasangan untuk melakukan kegiatan diskusi menentukan menentukan jawaban atas pertanyaan. Dan diakhiri dengan "sharing" meminta kepada pasangan-pasangan untuk berbagi dengan keseluruhan kelas yang mereka bicarakan atau hasil diskusi pasangan telah selesai dilakukan.

strategi pembelajaran Think Pair Share (TPS) merupakan strategi pembelajaran yang memperkenalkan gagasan tentang waktu "tunggu atau berpikir" (wait or think time) pada elemen interaksi pembelajaran kooperatif yang saat ini menjadi saah satu faktor ampuh dalam meningkatkan respon siswa terhadap pertanyaan atau memecahkan masalah pada proses pembelajaran siswa untuk menulis teks anekdot dengan katakatanya sendiri menggunakan bahasa yang lucu, humor, dan berisi sindiran. Sehingga memungkinkan siswa untuk bekerja sendiri dan bekerja sama dengan orang lain untuk menunjukkan partisipasi mereka pada saat memberi kesempatan kepada orang lain. 


\section{METODE}

Metode yang digunakan dalam penelitian ini adalah metode deskripstif dengan bentuk penelitiannya penelitian tindakan kelas. Subjek penelitian adalah siswa kelas X IS 4 SMA Negeri 1 Tebas Kabupaten Sambas, yang berjumlah 36 orang yang terdiri dari 22 siswa perempuan dan 14 siswa laki-laki, serta guru bahasa Indonesia yang mengajar di kelas X SMA Negeri 1 Tebas yang bernama Ibu Rusdiana, S.Pd. Setting penelitian merupakan tempat dan waktu penelitian yang akandilaksanakan. Adapun setting penelitian ini adalah di kelas X IS 4 SMA Negeri 1 Tebas Kabupaten Sambas, yang beralamatkan di Jalan pembangunan No.30, Kecamatan Tebas Kabupaten Sambas.

Teknik yang digunakan dalam penelitian ini terdiri dari empat Teknik yaitu Teknik observasi langsung, Teknik komunikasi langsung, Teknik pengukutran, dan Teknik documenter. Alat pengumpul data yang digunakan terdiri dari lembar observasi, lembar wawancara, tes unjuk kerja menulis teks anekdot, dan dokumen-dokumen yang berkaitan dengan pengumpulan data.

Teknik analisis data yang digunakan yaitu Teknik statistic deskriptif komperatif yang digunakan untuk data kuantitatif yaitu dengan membandingkan hasil antara siklus. Peneliti membendingkan hasil sebelum penelitian dengan hasil pada akhir setiap siklus. Teknik yang kedua yaitu Teknik analisis kritis.

\section{HASIL DAN PEMBAHASAN}

\section{Proses Pembelajaran Teks Anekdot}

Penelitian tindakan kelas ini merupakan penelitian yang dilakukan dengan cara melakukan tindakan pada pembelajaran di kelas dalam rangka mencapai tujuan untuk mencari solusi permasalahan yang terdapat pada suatu kelas. Pada pelaksanaan penelitian ini. Berdasarkan pada permasalahan yang dirumuskan, dengan menggunakan strategi pembelajaran think pair share dapat meningkatkan kemampuan menulis teks anekdot. Hal ini dapat dibuktikan dari perbandingan nilai dari pratindakan, siklus 1 dan siklus II, dengan demikian pada pembahasan ini akan dikemukakan mengenai hasil pengamatan dan hasil kemampuan siswa dalam menanggapi materi menulis teks anekdot menggunakan strategi pembelajaran think pair share.

Pada pelaksanaan penelitian siklus 1 untuk perolehan hasil pengamatan berdasarkan analisis data yang diperoleh dari lembar observasi siswa dan guru menggunakan strategi pembelajaran think pair share masih belum dapat dikatakan berjalan dengan baik karena berdasarkan 
pada hasil analisis observasi siswa, untuk perolehan nilai secara persentase adalah $69,23 \%$ yang mendapat nilai tuntas, dan untuk perolehan hasil pengamatan kegiatan pembelajaran guru diperoleh hasil persentase $73,33 \%$. Pada tahap refleksi yang telah dilakukan pada siklus 1 berdasarkan hasil pengamatan pada lembar observasi siswa dan guru disimpulkan bahwa masih terdapat kelemahan baik guru yang menerapkan strategi pembelajaran think pairshare dan siswa yang menerima pemahaman dari penerapan guru terhadapmateri yang telah diajarkan. Sedangkan berdasarkan pada pelaksanaan kegiatan siklus II baik dari hasil pengamatan siswa dan guru disimpulkan bahwa pelaksanaan yang dilakukan sudah menunjukkan perubahan atau peningkatan jika dibandingkan dengan pelaksanaan pembelajaran pada siklus 1. Adapun untuk perolehan hasil pengamatan pembelajaran siswa pada siklus II terhitung persentase $81,53 \%$ dan untuk perolehan hasil pengamatan pada pelaksanaan pembelajaran guru terhitung persentasenya adalah $85,00 \%$ kategori sangat baik.

\section{Hasil Pembelajaran Teks Anekdot}

Berdasarkan pada hasil pengamatan tindakan di atas, bahwa kemampuan siswa dalam menulis teks anekdot baik pratindakan dengan menggunakan metode yang konvensional hingga kegiatan siklus 1 dan siklus II setelah menggunakan strategi pembelajaran think pair share terlihat telah mengalami peningkatan. Hal ini dapat dilihat dari tingkat ketuntasan hasil belajar siswa sebanyak 36 siswa yang mampu mencapai nilai KKM dalam menulis teks anekdot, yaitu para pratindakan terdapat 15 orang siswa (42\%) yang mendapatkan nilai di atas KKM, pada siklus 1 terdapat 23 orang $(63 \%)$ yang mendapatkan nilai di atas KKM, dan pada siklus 2 terdapat 30 orang $(83 \%)$ yang mendapatkan nilai di atas KKM.

Berdasarkan pada hal tersebut, maka untuk melihat lebih jelas dalam peningkatan kemampuan menulis teks anekdot siswa menggunakan strategi pembelajaran think pair share dapat dilihat pada rekapitulasi penilaian hasil belajar pada pratindakan, siklus 1 dan siklus II pada tabel berikut ini.

Tabel 1

Rekapituasi Nilai individu siswa menulis teks anekdot

\begin{tabular}{c|l|c|c|c}
\hline No & Nama Siswa & Pratindakan & Siklus 1 & Siklus 2 \\
\hline 1 & Ardea Safitri & 68 & 66 & 68 \\
\hline 2 & Ardi & 62 & 62 & 78 \\
\hline 3 & Arisandi & 76 & 76 & 78 \\
\hline
\end{tabular}




\begin{tabular}{|c|c|c|c|c|}
\hline 4 & Dienda Amira & 76 & 78 & 82 \\
\hline 5 & Dikha Darmansyah & 70 & 72 & 76 \\
\hline 6 & Dina & 74 & 76 & 78 \\
\hline 7 & Elita Aurellia & 56 & 74 & 78 \\
\hline 8 & Feriz Kurniawan & 76 & 76 & 78 \\
\hline 9 & Gunardi & 80 & 78 & 76 \\
\hline 10 & Hardiyanti & 62 & 64 & 68 \\
\hline 11 & Ira Aprillia & 80 & 88 & 92 \\
\hline 12 & Juliani & 76 & 76 & 86 \\
\hline 13 & Khairun Alfi. S & 58 & 76 & 78 \\
\hline 14 & Kiki Nurhidayanti & 80 & 78 & 76 \\
\hline 15 & Maulana & 82 & 86 & 84 \\
\hline 16 & Messi & 66 & 72 & 78 \\
\hline 17 & Nolin Natasya & 66 & 74 & 76 \\
\hline 18 & Nopi Lestari & 68 & 64 & 68 \\
\hline 19 & Raihan Abidin & 58 & 68 & 68 \\
\hline 20 & Resi Ramadhanita & 78 & 76 & 78 \\
\hline 21 & Rinda Yulinda & 78 & 76 & 82 \\
\hline 22 & Riskan Apriandi & 84 & 88 & 86 \\
\hline 23 & Salsa Agustin & 62 & 58 & 80 \\
\hline 24 & Sasmita Sari & 78 & 78 & 76 \\
\hline 25 & Sindi & 78 & 78 & 78 \\
\hline 26 & Tedi & 78 & 76 & 86 \\
\hline 27 & U. Adelia Putri. S & 64 & 82 & 78 \\
\hline 28 & Ustari Sifakurwanti & 76 & 78 & 76 \\
\hline 29 & Wandi Sabana & 66 & 80 & 86 \\
\hline 30 & Weldi & 66 & 82 & 78 \\
\hline 31 & Wenni & 70 & 76 & 84 \\
\hline 32 & Werry & 74 & 68 & 74 \\
\hline 33 & Yeni & 58 & 78 & 78 \\
\hline 34 & Yuliana & 68 & 80 & 76 \\
\hline 35 & Yusdi & 62 & 58 & 76 \\
\hline 36 & Yusrian & 56 & 68 & 70 \\
\hline \multicolumn{2}{|c|}{ Jumlah } & 2546 & 2684 & 2808 \\
\hline & Rata-rata & 70,72 & 74,55 & 78,00 \\
\hline
\end{tabular}

Berdasarkan hasil kinerja secara individu pada tabel di atas, dimulai dari pratindakan, siklus 1, dan siklus II sangat terlihat adanya perbedaan dalam peningkatan nilai siswa rata-rata pada kemampuan menulis teks anekdot, yaitu pada pratindakan terdapat nilai rata-rata sebesar 70,72 berkategori (cukup), selanjutnya untuk siklus 1 dengan nilai rata-rata sebesar 74,55 berkategori 
(cukup), dan pada siklus 2 dengan nilai rata-rata sebesar 78,00 berkategori (baik).
Untuk melihat peningkatan hasil belajar siswa dapat dilihat dalam bentuk tabel berikut:

Tabel 2

\section{Rekapitulasi Persentase Nilai Individu Siswa Menulis Teks Anekdot}

\begin{tabular}{|c|c|c|c|c|}
\hline $\begin{array}{c}\text { Rentang } \\
\text { Nilai }\end{array}$ & Keterangan & Pra Siklus & Siklus I & Siklus II \\
\hline $80-100$ & Sangat Baik & $14 \%$ & $19 \%$ & $28 \%$ \\
\hline $75-79$ & Baik & $28 \%$ & $44 \%$ & $54 \%$ \\
\hline $70-74$ & Cukup & $11 \%$ & $11 \%$ & $6 \%$ \\
\hline $65-69$ & Kurang & $19 \%$ & $11 \%$ & $6 \%$ \\
\hline$<65$ & Sangat kurang & $28 \%$ & $15 \%$ & $6 \%$ \\
\hline \multicolumn{2}{|c|}{ JUMLAH } & $100 \%$ & $100 \%$ & $100 \%$ \\
\hline
\end{tabular}

Nilai siswa sebelum diberikan tindakan masih sangat kurang. Hal itu dapat dilihat dari siswa yang memiliki kriteria sangat baik hanya 5 siswa (14\%), kategori baik 10 siswa (28\%), kategori cukup 4 siswa (11\%), kategori kurang 7 siswa (19\%), dan kategori kurang sekali 10 siswa (28\%). Setelah siklus I, nilai mengalami peningkatan kriteria sangat baik naik menjadi 7 siswa (19\%), kategori baik 16 siswa (44\%), kategori cukup 4 siswa (11\%), kategori kurang 4 siswa (11\%), dan kategori kurang sekali 5 siswa (15\%). Sedangkan setelah siklus II, peningkatan nilai siswa dengan kriteria sangat baik 10 siswa (28\%), kategori baik 20 siswa (54\%),kategori cukup 2 siswa (6\%), kategori kurang 2 siswa (6\%), dan kategori kurang sekali 2 siswa (6\%).

Berdasarkan hasil analisis data dalam penelitian tentang kemampuan menulis teks anekdot menggunakan strategi pembelajaran think pair share pada siswa kels X IS 4 SMA Negeri 1 Tebas KabupatenSambas, bahwa terdapat peningkatan hasil belajar siswa secara individu. Maka dapat disimpulkan bahwa dalam strategi pembelajaran think pairshare dapat meningkatkan kemampuan siswa dalam menulis teks anekdot.

\section{SIMPULAN}

Hasil analisis data dan hasil pembahasan dalam penelitian yang telah diperoleh dari pelaksanaan tindakan, maka dapat disimpulkan secara umum bahwa melalui penelitian tindakan kelas (PTK) terdapat peningkatan yang sangat signifikan atau dikategorikan baik terhadap kemampuan menulis teks anekdot dengan menggunakan strategi pembelajaran think pair share pada siswa kelas X IS 4 SMA Negeri 1 Tebas Kabupaten Sambas. Hal ini 
dapat menunjukkan bahwa hasil yang baik telah diperoleh dan mencapai Kriteria Ketuntasan Maksimum (KKM). Secara khusus dapat disimpulkan sebagai berikut. Pertama, proses pembelajaran kemampuan menulis teks anekdot dengan menggunakan strategi pembelajaran think pair share pada siswa kelas X IS 4 SMA Negeri 1 Tebas Kabupaten Sambas berjalan dengan lancar sesuai dengan rencana pada setiap siklus. Hal ini dapat dilihat dari hasil lembaran pengamatan tindakan pada siswa dalam proses pembelajaran pada pratindakan terdapat $42 \%$, siklus 1 mencapai $69,23 \%$ meningkat menjadi $81,53 \%$ pada siklus II. Kemudian, dari hasil pengamatan guru dengan menggunakan strategi pembelajaran think pair share pada siklus 1 dari $73,33 \%$ meningkat menjadi $85,00 \%$ pada siklus II. Kedua, hasil kemampuan menulis teks anekdot pada siswa kelas X IS 4 SMA Negeri 1 Tebas Kabupaten Sambas telah mengalami peningkatan dengan menggunakan strategi pembelajaran think pair share dan hal ini dapatdilihat berdasarkan hasil kinerja siswa secara individu. Perolehan hasil nilai kinerja siswa secara individu pada saat pra tindakan diperoleh dari rata-rata 70,72 meningkat menjadi 74,55 pada siklus 1 , kemudian pada siklus II mengalami peningkatan dari siklus 1 dengan perolehan nilai rata-rata menjadi 78,00.

\section{DAFTAR PUSTAKA}

Keraf, Gorys. (1981). Argumentasi dan Narasi. Jakarta: PT Gramedia

Kusumaningsih, Dewi, $\operatorname{Dkk}(2013)$, Terampil Berbahasa Indonesia. Yogyakarta: Andi

Nurgiyantoro, Burhan. (2010). Penilaian Pembelajaran Bahas Berbasis Kompetensi. Yogyakarta: BPFE

Semi, atar. (2007). Dasar-dasar Keterampilan Menulis. Bandung: Angkasa.

Tarigan, H. G. (2008). Menulis Sebagai Suatu Keterampilan Berbahasa. Bandung: Angkasa Bandung 